\title{
Vitamin D status in pregnant women and their newborns in a tertiary care hospital
}

\author{
Harleen Kour, Shashi Gupta, Swarn K. Gupta, Bawa Ram Bhagat, Gagan Singh*
}

Department of Obstetrics and Gynecology, Government Medical College, Jammu, Jammu and Kashmir, India

Received: 06 October 2018

Accepted: 27 October 2018

\section{*Correspondence:}

Dr. Gagan Singh,

E-mail: gaganbhau@gmail.com

Copyright: () the author(s), publisher and licensee Medip Academy. This is an open-access article distributed under the terms of the Creative Commons Attribution Non-Commercial License, which permits unrestricted non-commercial use, distribution, and reproduction in any medium, provided the original work is properly cited.

\begin{abstract}
Background: In the recent years there has been an increased understanding of the role that vitamin D plays in regulation of cell growth, calcium absorption and immunity and its impact on the developing fetus and maternal health is of significant concern. This study aims at evaluating the Vitamin D status in pregnant women and their newborns.

Methods: A cross sectional study was done on 100 pregnant females according to inclusion and exclusion criteria. At the time of delivery, maternal blood was collected, and newborn samples were taken from newborn side of umbilical cord and sent for analysis.

Results: The prevalence of Vitamin D deficiency has been found to be $85 \%$ of pregnant females and $91 \%$ of the newborns. Only $5 \%$ of pregnant females and $1 \%$ of the newborns showed Vitamin D sufficiency. Maternal and newborn vitamin D levels show a positive correlation. Mean maternal and newborn Vitamin D levels were found to be $16.78 \pm 7.04 \mathrm{ng} / \mathrm{mL}$ and $11.29 \pm 5.75 \mathrm{ng} / \mathrm{ml}$.

Conclusions: Vitamin D deficiency is highly prevalent among pregnant women in north India. Low maternal vitamin D levels lead to vitamin D deficiency in the newborns also.
\end{abstract}

Keywords: Newborn, Pregnant female, Vitamin D

\section{INTRODUCTION}

Vitamin D is an important vitamin in the body. The impact of vitamin $\mathrm{D}$ deficiency on the developing fetus and maternal health is of significant concern. Because 25hydroxy Vitamin D crosses the placenta, fetal and cord blood levels of the newborn Vitamin D status correlate with the mother levels of Vitamin D. ${ }^{1}$

Vitamin D can be synthesized in sufficient amounts by most vertebrates on adequate exposure of the skin to sunlight (UVB rays). Skin synthesis of Vitamin D depends mainly on factors like age, degree of skin pigmentation and amount of UVB radiation reaching the earth surface. The term vitamin D refers to compounds
Vitamin $\mathrm{D}_{3} \quad$ (cholecalciferol) or vitamin $\mathrm{D}_{2}$ (ergocalciferol). Vitamin $\mathrm{D}_{3}$ is produced in the skin on exposure to sunlight. Vitamin $\mathrm{D}$ (both forms $\mathrm{D}_{3}$ or $\mathrm{D}_{2}$ ) is a pro-hormone which requires two hydroxylations to finally attain its biologically active form-1,25dihydroxy Vitamin D or $1,25(\mathrm{OH})_{2} \mathrm{D}$. It is released in blood, where it binds to vitamin $\mathrm{D}$ binding protein (VDBP) and reaches its target tissues to exert its endocrine functions through the vitamin D receptor (VDR). During pregnancy, the placenta is probably the most prominent site for extra renal activation of Vitamin D. Because the half-life of $1,25-(\mathrm{OH})_{2} \mathrm{D}$ is only several minutes, the more accurate assessment of an individual's Vitamin D status is determined through measurement of 25-OH-D which has a half-life of about three weeks. 
Vitamin D deficiency prevails in epidemic proportions all over the Indian subcontinent, with a prevalence of $70 \%$ $100 \%$ in the general population. ${ }^{2}$ In a population that already has a high prevalence of Vitamin D deficiency and poor dietary calcium intake, the problem is likely to worsen during pregnancy because of active trans placental transport of calcium to developing fetus. Vitamin D status of these mothers correlated well with their neonates and their exclusively breastfed infants.

Vitamin D deficiency in pregnancy has been shown to lead to significant pregnancy complications like preeclampsia, gestational diabetes, intrahepatic cholestasis of pregnancy, periodontal disease and high caesarean rates. ${ }^{3-5}$ Vitamin D deficiency is also associated with bacterial vaginosis in pregnant women.

Gestational Vitamin D deficiency also has adverse effects on neonatal health including small for gestational age fetus, low birth weight, neonatal hypocalcaemia seizures, delayed skeletal development, etc. ${ }^{6,7}$ For the majority of women who are deficient in Vitamin D, treatment for 4-6 weeks, either with cholecalciferol 20,000 IU a week or ergocalciferol 10,000 IU twice a week, followed by standard supplementation, is appropriate.

For women who require short-term repletion, 20,000 IU weekly appears to be safe and effective treatment of Vitamin D deficiency. A daily dose is likely to be appropriate to maintain subsequent repletion (1000 IU daily). ${ }^{8}$

There is no data to support routine screening for Vitamin $\mathrm{D}$ deficiency in pregnancy in terms of health benefits or cost effectiveness. As the test is expensive, offering it to all at risk women may not be cost effective compared to offering universal supplementation, particularly as treatment is regarded as being very safe.

\section{METHODS}

The present study was conducted in Department of Obstetrics and Gynaecology, Government Medical College, Jammu for a period of one year (November 2015 to October 2016). 100 pregnant females admitted for delivery were selected randomly according to inclusion and exclusion criteria.

\section{Inclusion criteria}

- Primigravida with full term singleton pregnancy.

\section{Exclusion criteria}

- Pregnant women with pre-existing thyroid disorders, parathyroid or calcium metabolism disorders or who took medications that interfere with calcium or vitamin D metabolism such as diuretics or calcium channel blockers, women suffering from bone, renal, adrenal and gastrointestinal disorders and other chronic or current medical illness or with history of ATT or anti-epileptic drugs intake.

After informed consent was obtained, information regarding exposure to sunlight, education and socioeconomic status was also noted Blood samples was collected from all the subjects prior to delivery or during early labor. Newborn blood samples were collected from the newborn's side of severed umbilical cord at time of delivery.

About $2 \mathrm{ml}$ blood sample was collected in a plain test tube without any anti-coagulant and was then stored in refrigerator until analysis. Vitamin $\mathrm{D}$ deficiency is defined as $25(\mathrm{OH}) \mathrm{D}<20 \mathrm{ng} / \mathrm{ml}$, Vitamin D Insufficiency as $21-29 \mathrm{ng} / \mathrm{ml}$ and sufficiency as $\geq 30 \mathrm{ng} / \mathrm{ml}$ (according to Endocrine Society).

At the end of the study, all the data collected was compiled and analyzed using appropriate statistical tests. A prevalence of $<0.05$ is considered as statistical significance.

\section{RESULTS}

The present study was conducted in100 pregnant females and their newborns and following results were obtained. Maximum number of females $(65 \%)$ belonged to the age group of 21-25 years. The mean age was 24.20 \pm 3.29 years. Prevalence of hypovitaminosis D in this age group is $93.84 \%$. In the age group $\leq 20$ years, $100 \%$ females had Hypovitaminosis D. Females with age $>30$ years, $66.66 \%$ had vitamin D deficiency and $33.33 \%$ had sufficient levels (Table 1).

Table 1: Maternal age and vitamin D status.

\begin{tabular}{|llllll|}
$\begin{array}{l}\text { Age group } \\
\text { (in years) }\end{array}$ & $\begin{array}{l}\text { Number of } \\
\text { females } \mathbf{N}(\%)\end{array}$ & $\begin{array}{l}\text { Maternal vit D levels }(\mathbf{n g} / \mathbf{m l}) \\
\mathbf{2 0}(\mathbf{\%})\end{array}$ & $\mathbf{2 0 - 3 0}(\mathbf{\%})$ & $\mathbf{> 3 0}(\mathbf{\%})$ & $\begin{array}{l}\text { Prevalence of } \\
\text { hypovitaminosis D }(\mathbf{9 5} \% \mathbf{C I})\end{array}$ \\
\hline$\leq 20$ & $12(12 \%)$ & $8(66.66 \%)$ & $4(33.33 \%)$ & 0 & $100 \%(77.91-100)$ \\
\hline $21-25$ & $65(65 \%)$ & $57(87.69 \%)$ & $4(6.15 \%)$ & $4(6.15 \%)$ & $93.84 \%(85.82-98.01)$ \\
\hline $26-30$ & $20(20 \%)$ & $17(85 \%)$ & $2(10 \%)$ & $1(5 \%)$ & $95 \%(77.72-99.75)$ \\
\hline$>30$ & $3(3 \%)$ & $2(66.66 \%)$ & 0 & $1(33.33 \%)$ & $66.66 \%(13.2-98.33)$ \\
\hline Total & $100(100 \%)$ & 85 & 10 & 5 & $95 \%(89.27-98.15)$ \\
\hline
\end{tabular}

*For the purpose of analysis categories of Vit. D<20 ng/ml and Vit. D 20-30 ng/ml are clubbed together. 
Table 2: Residence and maternal vitamin D status.

\begin{tabular}{|llllll|} 
Residence & $\begin{array}{l}\text { Number of } \\
\text { females N }(\%)\end{array}$ & \multicolumn{2}{c}{ Maternal vit D levels $(\mathrm{ng} / \mathrm{ml})$} & & \multicolumn{2}{l|}{$\begin{array}{l}\text { Prevalence of } \\
\text { hypovitaminosis D (95\% CI) }\end{array}$} \\
\hline Urban & $61(61 \%)$ & $50(81.96 \%)$ & $7(11.47 \%)$ & $4(6.55 \%)$ & $93.44 \%(84.94-97.88)$ \\
\hline Rural & $39(39 \%)$ & $35(89.74 \%)$ & $3(7.69 \%)$ & $1(2.565 \%)$ & $97.43 \%(88-99.87)$ \\
\hline Total & $100(100 \%)$ & $85(85 \%)$ & $10(10 \%)$ & $5(5 \%)$ & $95 \%(89.27-98.15)$ \\
\hline
\end{tabular}

*For the purpose of analysis categories of Vit. D<20 ng/ml and Vit. D 20-30 ng/ml are clubbed together.

$\mathrm{p}$ value $=0.3739$ by Mantel-Haenszel chi square test (not significant).

Table 3: Maternal education and vitamin D status.

\begin{tabular}{|llllll|}
$\begin{array}{l}\text { Educational } \\
\text { status }\end{array}$ & $\begin{array}{l}\text { Number of } \\
\text { females } \mathbf{N}(\%)\end{array}$ & $\begin{array}{l}\text { Maternal vit D levels }(\mathbf{n g} / \mathbf{m l}) \\
\mathbf{< 2 0}(\mathbf{\%})\end{array}$ & $\mathbf{2 0 - 3 0}(\mathbf{\%})$ & $\mathbf{> 3 0}(\mathbf{\%})$ & $\begin{array}{l}\text { Prevalence of } \\
\text { hypovitaminosis D (95\% CI) }\end{array}$ \\
\hline Uneducated & $6(6 \%)$ & $5(83.33 \%)$ & $1(16.66 \%)$ & 0 & $100 \%(60.7-100)$ \\
\hline${\text { Up to } 10^{\text {th }}}_{10^{\text {th }} \text { to } 12^{\text {th }}}$ & $56(56 \%)$ & $53(94.64 \%)$ & $2(3.57 \%)$ & $1(1.78 \%)$ & $98.21 \%(91.51-99.91)$ \\
\hline Above $12^{\text {th }}$ & $28(28 \%)$ & $19(67.85 \%)$ & $6(21.42 \%)$ & $3(10.71 \%)$ & $89.28 \%(73.55-97.2)$ \\
\hline Total & $10(10 \%)$ & $8(80 \%)$ & $1(10 \%)$ & $1(10 \%)$ & $90 \%(59.65-99.5)$ \\
\hline
\end{tabular}

*For the purpose of analysis categories of Vit. D $<20 \mathrm{ng} / \mathrm{ml}$ and Vit. D 20-30 ng/ml are clubbed together.

Extended Mantel-Haenszel chi square for linear trend $=4.27$. p-value $(1$ degree of freedom $)=0.03868$ (significant).

Table 4: Reported exposure to sunlight and maternal vitamin D status.

\begin{tabular}{|llllll|}
$\begin{array}{l}\text { Exposure to sunlight } \\
\text { (in hours) }\end{array}$ & $\begin{array}{l}\text { Number of } \\
\text { females } \mathbf{N}(\%)\end{array}$ & $\begin{array}{l}\text { Maternal vit D levels }(\mathbf{n g} / \mathbf{m l}) \\
\mathbf{2 0}(\mathbf{\%})\end{array}$ & $\mathbf{2 0 - 3 0}(\mathbf{\%})$ & $\mathbf{> 3 0}(\mathbf{\%})$ & $\begin{array}{l}\text { Prevalence of } \\
\text { hypovitaminosis D }(\mathbf{9 5} \% \mathbf{C I})\end{array}$ \\
\hline$<1$ & $35(35 \%)$ & $33(94.28 \%)$ & $1(2.85 \%)$ & $1(2.85 \%)$ & $97.14 \%(86.71-99.86)$ \\
\hline $1-2$ & $57(57 \%)$ & $45(78.94 \%)$ & $8(14.03 \%)$ & $4(7.01 \%)$ & $92.98 \%(83.94-97.73)$ \\
\hline$>2$ & $8(8 \%)$ & $7(87.5 \%)$ & $1(12.5 \%)$ & 0 & $100 \%(68.77-100)$ \\
\hline Total & $100(100 \%)$ & $85(85 \%)$ & $10(10 \%)$ & $5(5 \%)$ & $95 \%(89.27-98.15)$ \\
\hline
\end{tabular}

*For the purpose of analysis categories of Vit. D<20 ng/ml and Vit. D 20-30 ng/ml are clubbed together.

Extended Mantel-Haenszel chi square for linear trend $=0.42$. p-value $(1$ degree of freedom $)=0.5161$ (not significant).

Table 5: Maternal and neonatal vitamin D levels.

\begin{tabular}{|llllll|}
\hline $\begin{array}{l}\text { Neonatal vitamin D } \\
\text { levels }(\mathbf{n g} / \mathbf{m l})\end{array}$ & $\begin{array}{l}\text { Number of } \\
\text { babies } \mathbf{N}(\%)\end{array}$ & $\begin{array}{l}\text { Maternal vit D levels }(\mathbf{n g} / \mathbf{m l}) \\
\mathbf{2 0}(\boldsymbol{\%})\end{array}$ & $\mathbf{2 0 - 3 0}(\mathbf{\%})$ & $\mathbf{> 3 0}(\mathbf{\%})$ & Prevalence $(\mathbf{9 5} \% \mathbf{C I})$ \\
\hline$<20$ & $91(91 \%)$ & $85(93.40 \%)$ & $6(6.59 \%)$ & 0 & $100 \%(96.76-100)$ \\
\hline $20-30$ & $8(8 \%)$ & 0 & $4(50 \%)$ & $4(50 \%)$ & $50 \%(18.41-81.59)$ \\
\hline$>30$ & $1(1 \%)$ & 0 & 0 & $1(100 \%)$ & $0 \%(0.0-95)$ \\
\hline Total & $100(100 \%)$ & $85(85 \%)$ & $10(10 \%)$ & $5(5 \%)$ & $95 \%(89.27-98.15)$ \\
\hline
\end{tabular}

Table 6: Maternal and neonatal vitamin D status.

\begin{tabular}{|lllll|}
$\begin{array}{l}\text { Vitamin D levels } \\
(\mathbf{n g} / \mathbf{m l})\end{array}$ & $\begin{array}{l}\text { No. of pregnant } \\
\text { females }\end{array}$ & $\begin{array}{l}\text { Prevalence } \\
(95 \% \mathrm{CI})\end{array}$ & $\begin{array}{l}\text { No. of } \\
\text { newborns }\end{array}$ & $\begin{array}{l}\text { Prevalence } \\
(95 \% \text { CI })\end{array}$ \\
\hline$<20$ (Deficiency) & 85 & $85 \%(76.98-91.02)$ & 91 & $91 \%(84.13-95.52)$ \\
\hline $20-30$ (Insufficiency) & 10 & $10 \%(5.19-17.1)$ & 8 & $8 \%(3.785-14.62)$ \\
\hline$>30$ (Sufficiency) & 5 & $5 \%(1.85-10.73)$ & 1 & $1 \%(0.050-4.832)$ \\
\hline Total & 100 & & 100 & \\
\hline
\end{tabular}

$61 \%$ of the females belonged to urban area and $39 \%$ from rural area. It was observed that women from rural areas are more deficient in Vitamin D as compared to the urban females. Out of the 39 rural women, 35(89.74\%) were found to have Vitamin D deficiency, 3(7.69\%) had insufficiency and only one woman (2.565\%) had sufficient levels of Vitamin D. Out of the 61 urban women, $50(81.96 \%)$ were found to have Vitamin D deficiency, $7(11.47 \%)$ had insufficiency and only 4 woman $(6.55 \%)$ had sufficient levels of Vitamin D.

Mean maternal Vitamin D levels amongst the rural and the urban women is $14.75 \pm 6.30 \mathrm{ng} / \mathrm{mL}$ and $18.08 \pm 7.23$ $\mathrm{ng} / \mathrm{mL}$ respectively. Prevalence of hypovitaminosis $\mathrm{D}$ is 
97.43\% amongst the rural females as compared to $93.44 \%$ among the urban women (Table 2).

$56 \%$ females had attained formal education up to $10^{\text {th }}$ class, $6 \%$ were uneducated and Only $10 \%$ had attained education above 12th class. Mean maternal Vitamin D levels amongst the different educational groups were calculated and found as follows- Uneducated-12.88 \pm 6.99 $\mathrm{ng} / \mathrm{ml} ; \mathrm{Up}$ to $10^{\text {th }}$ class $-14.86 \pm 4.77 \mathrm{ng} / \mathrm{ml} ; 10^{\text {th }}$ to $12^{\text {th }}$ class-20.77 $\pm 8.94 \mathrm{ng} / \mathrm{ml}$ and above $12^{\text {th }}$ class-18.70 \pm 7.34 $\mathrm{ng} / \mathrm{ml}$. Prevalence of hypovitaminosis D was maximum amongst the illiterate females $100 \%$ (Table 3). Significant association was found between maternal education and vitamin D status ( $\mathrm{p}$-value $=0.03)$.

57 females (57\%) had reported an exposure to sunlight only for 1-2 hours in a day. Only $8 \%$ females had exposure more than 2 hours. It was observed that females with minimum hours of exposure to sunlight ( $<1$ hour) were most deficient in Vitamin D, i.e. $94.28 \%$. Mean maternal vitamin D level is $15.19 \pm 5.43 \mathrm{ng} / \mathrm{mL}$ in such females. Amongst the females who had reported sunlight exposure of more than 2 hours, $87.5 \%$ had deficient levels of vitamin D. Prevalence of hypovitaminosis D amongst the group of females with 1-2 hours reported exposure to sunlight, which includes maximum number of females, is $92.98 \%$ (Table 4).

In the present study, prevalence of vitamin $\mathrm{D}$ deficiency has been found in $85 \%$ of the pregnant females. $10 \%$ females had vitamin D insufficiency and only $5 \%$ females had sufficient levels of Vitamin D (Table 5 and 6). Prevalence of hypovitaminosis $\mathrm{D}$ i.e. taking together vitamin D deficiency and insufficiency is $95 \%$. Mean maternal vitamin D level is $16.78 \pm 7.04 \mathrm{ng} / \mathrm{ml}$.

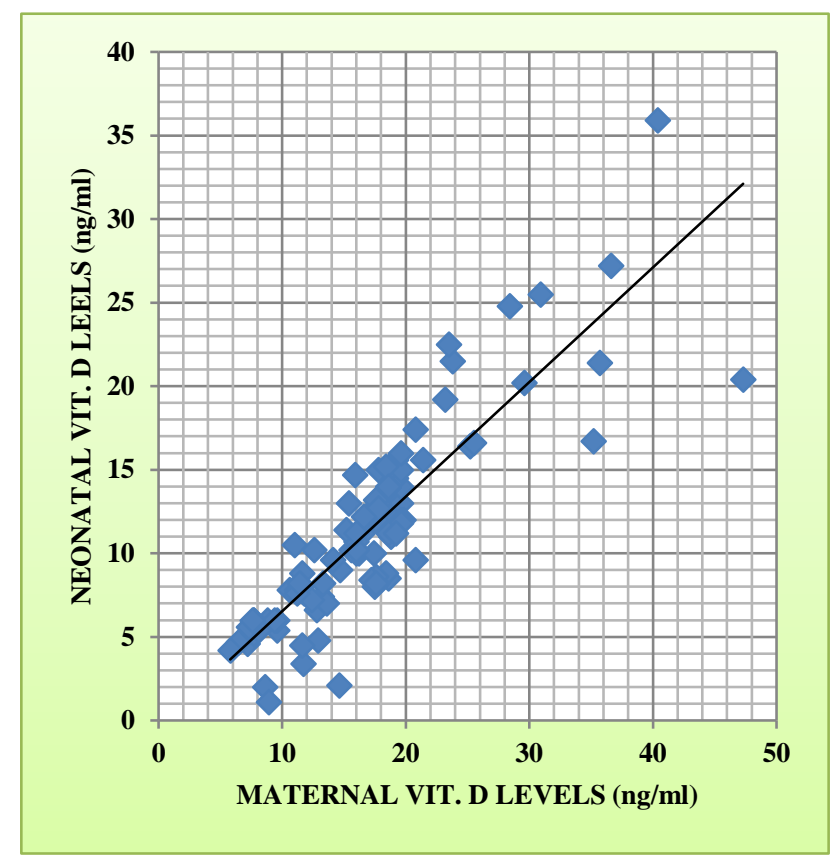

Figure 1: Correlation between maternal and neonatal vitamin D levels.
Prevalence of Vitamin D deficiency amongst the newborns is $91,8 \%$ had vitamin D insufficiency and only $1 \%$ had sufficient levels of vitamin D. Mean newborn vitamin D level is $11.29 \pm 5.75 \mathrm{ng} / \mathrm{ml}$. All the Vitamin D deficient mothers i.e. $85 \%$, delivered babies who were Vitamin D deficient. A positive co-relation was found between the maternal and neonatal vitamin D levels (Figure 1).

\section{DISCUSSION}

The mean age in present study was $24.20 \pm 3.29$ years which was comparable to study conducted by Sharma et al. ${ }^{9}$ where mean age was $23 \pm 5.85$ years. Females $\leq 20$ and $\geq 30$ years had prevalence of hypovitaminosis $\mathrm{D}$ of $100 \%$ and $66.66 \%$ respectively, which was similar to study by Al Faris NA where prevalence of vitamin D deficiency in younger females was $53.2 \%$ and $38.2 \%$ in older females. ${ }^{10}$ However, no significant association was found between maternal age and vitamin D status as concluded by Sharma et al. ${ }^{9}$

$61 \%$ females belonged to urban areas and $39 \%$ to rural areas. Vitamin D deficiency was found more amongst the rural pregnant females $(89.74 \%)$. Prevalence of hypovitaminosis D was higher in rural females. Association of maternal Vitamin D status and residence was not found to be statistically significant in present study which was comparable to Study conducted by Sachan et al where mean maternal vitamin D levels in the urban and rural women did not differ significantly. ${ }^{11}$

$56 \%$ female had attained formal education up to $10^{\text {th }}$ class and only $10 \%$ above $12^{\text {th }}$ class. $6 \%$ of females were uneducated. Prevalence of hypovitaminosis D among the illiterate females was $100 \%$. Significant association was found between maternal education and vitamin D status (p-value $=0.03$ ) in present study which was comparable to study by Sharma et al. ${ }^{9}$ who found that amongst the illiterate women prevalence of hypovitaminosis D was $95.74 \%$.

$57 \%$ females reported an exposure to sunlight for 1-2 hours in a day. No significant correlation was found between vitamin D status and sunlight exposure in present study. On the contrary in present study prevalence amongst the group who received sunlight for maximum time i.e. $>2$ hours were highest. This may possibly explained by the fact that actual hours of exposure to sunlight could not by calculated accurately by any means and moreover in present study authors have documented the hours of exposure as reported by the subjects which cannot be exact. Also, pigmented skin, excessive clothing and air pollution may interfere with Vitamin D synthesis on exposure to sunlight. Al Faleh et al in a study in Saudi Arabia found no association between maternal Vitamin D levels and level of sun exposure. ${ }^{12}$ In present study prevalence of Maternal and Neonatal vitamin D deficiency was $85 \%$ and $91 \%$ respectively which was comparable to study by Sachan et 
al $(84 \%)$, Halicioglu et al $(90.3 \%)$ and Wuertz $\mathrm{C}$ et al (94\%) respectively. ${ }^{11,13,14}$ A positive correlation was found between maternal and neonatal vitamin D levels.

\section{CONCLUSION}

Vitamin D deficiency is highly prevalent among pregnant women in north India. Low maternal Vitamin D levels lead to vitamin D deficiency in the newborns also. There is no data to support routine screening for Vitamin D deficiency in pregnancy in terms of health benefits or cost effectiveness. As the test is expensive, offering it to all at risk women may not be cost effective compared to offering universal supplementation, which is regarded as being very safe and may help in preventing vitamin D deficiency and its consequent complications.

Funding: No funding sources

Conflict of interest: None declared

Ethical approval: The study was approved by the Institutional Ethics Committee

\section{REFERENCES}

1. Greer FR. 25 hydroxy Vitamin D: Functional outcomes in infants and young children. Am J Clin Nutr. 2008;88(2):529S-33S.

2. Gupta R, Gupta. Vitamin D deficiency in India: prevalence, causalities and interventions. Nutrients. 2014;6(2):729-75.

3. Robinson CJ, Alanis MS, Wagner CL, Hollis BW, Johnson DD. Plasma 25-OH Vitamin D levels in early onset severe preeclampsia. Am J Obstet Gynaecol. 2010;203(4):366.

4. Zhang C, Qiu C, Hu FB, David RM, Van Dam RM, Bralley A, et al. Maternal 25-OH Vitamin D concentration and the risk of gestational diabetes mellitus. PLoS One. 2008;3:e3753.

5. Scholl TO, Chen X, Stein P. Maternal vitamin D status and delivery by cesarean. Nutrients. 2012;4(4):319-30.

6. Bodnar LM, Simhan HN, Powers RW, Frank MP, Cooperstein E, Roberts JM. High prevalence of vitamin D insufficiency in black and white pregnant women residing in the Northern United States and their neonates. J Nutr. 2007;137(2):447-52.

7. Agarwal N, Arya SC. Vitamin D3 levels in pregnant women and newborns at a private tertiary care hospital in Delhi, India. Int $\mathrm{J}$ Gynecol Obstet. 2011;113:240-1.

8. Kennel KA, Drake MT, Hurley DL. Vitamin D deficiency in adults: when to test and how to treat. Mayo Clin Proc. 2010;85:752-7.

9. Sharma S, Kumar A, Prasad S, Sharma S. Current scenario of vitamin D status during pregnancy in North Indian population. J Obstet Gynaecol India. 2016;66(2):93-100.

10. Al-Faris NA. High prevalence of vitamin D deficiency among pregnant Saudi women. Nutrients. 2016;8(2):77.

11. Sachan A, Gupta R, Das V, Agarwal A, Awasthi PK, Bhatia V. High prevalence of vitamin D deficiency among pregnant women and their newborns in northern India. Am J Clin Nutr. 2005;81:1060-4.

12. AlFaleh KM, Al-Manie AM, Al-Mahmoud HF, AlRazqan HM, Al-Mutlaq AB, Al-Rumaih SA, et al. Prevalence of Vitamin D deficiency in Saudi newborns at a tertiary care center. Saudi Med J. 2014;35(2):178-82.

13. Halicioglu O, Aksit S, Koc F, Akman SA, Albudak E, Yaprak I, et al. Vitamin D deficiency in pregnant women and their neonates in spring time in western Turkey. Paediatr Perinat Epidemiol. 2012;26(1):5360.

14. Wuertz C, Gilbert P, Baier W, Kunz C. Crosssectional study of factors that influence the 25hydroxyvitamin $\mathrm{D}$ status in pregnant women and in cord blood in Germany. Br J Nutr. 2013;110(10):1895-902.

Cite this article as: Kour H, Gupta S, Gupta SK, Bhagat BR, Singh G. Vitamin D status in pregnant women and their newborns in a tertiary care hospital. Int J Reprod Contracept Obstet Gynecol 2018;7:5071-5. 